УДК 81’1:82-92:070:929 (Донцов)

Супрун Л. В. доктор наук із соціальних комунікацій, професор, завідувач кафедри журналістики Національного університету «Острозька академія»

\title{
ВОЛЮНТАРИЗАЦІЯ УКРАЇНСЬКОЇ МОВНОЇ МЕНТАЛЬНОСТІ: ПРОПОЗИЦІЯ ДОНЦОВА-ПУБЛЦИСТА
}

У статті доводиться, що Дмитро Донцов своє журналістське покликання бачив у здійсненні волюнтаризації украӥнської ментальності. Недостатню репрезентацію волі в національному характері україниів головний редактор «Літературно-Наукового Вістника» («Вістника») уважсав його непростимою слабкістю, що прогнозує дуже сумнівне майбутне українського етносу. Зміні пріоритетів в украӥнській мовній ментальності підпорядкована, окрім іншого, імперативність стилю Донцова-публіциста, зокрема частотність директив, які спонукають до дії, гартують волю читачів часопису.

Ключові слова: Д. Донцов, «Літературно-Науковий Вістник» («Вістник»), українська мовна ментальність, волюнтаризаиія.

В статье доказывается, что Дмитрий Дониов свое журналистское призвание видел в осуществлении волюнтаризации украинской ментальности. Недостаточную репрезентацию воли в наџиональном характере украинцев главный редактор «Литературно-Научного Вестника» («Вестника») считал его непростительной слабостью, которая прогнозирует очень сомнительное будущее украинскому этносу. Смене приоритетов в украинской языковой ментальности подчинена, помимо другого, императивность стиля Донцова-публициста, в частности частотность директив, которые побуждают к действию, закаляют волю читателей журнала. 
Ключевые слова: Д. Донцов, «Литературно-Научный Вестник» («Вестник»), украинская языковая ментальность, волюнтаризачия.

In the article it is proved that D. Dontsov saw his journalistic vocation in the implementation of voluntarization of Ukrainian language mentality. The editor in chief of «Literary-Scientific Herald» («Herald») considered insufficiently representation of the will in Ukrainian national character as his unforgivable weakness, which predicts a dubious future of Ukrainian ethnos. The changing of priorities in Ukrainian language mentality is subordinated, among other things, the imperative of the style of Dontsov-publicist, in particular the frequency of directives, that energize, harden the will of readers of the magazine.

Key words: D. Dontsov, "Literary-Scientific Herald» («Herald»), Ukrainian language mentality, voluntarization.

Український національний характер - предмет постійного занепокоєння головного редактора «Літературно-Наукового Вістника» третього періоду його функціонування. Ця тема певним чином артикульована у працях таких дослідників, як Р. Безсмертний, Є. Єндик, М. Ільницький, С. Квіт, В. Кириленко, С. Кость, М. Леськова, М. Мандрик, Р. Олійник, О. Ситник, М. Сосновський, М. Чугуєнко, Ю. Шаповал, Т. Шептицька, В. Шкляр, І. Шліхта та ін. [див. детально: Супрун 2012].

Вісниківські попередники Д. Донцова І. Франко і М. Грушевський також намагалися позбавити вад українську ментальність: перший - шляхом іï європеїзації, другий покладався на інтелектуалізацію. Третій редактор ЛНВ обрав більш кардинальний вектор впливу, дослідження якого склало мету нашої статті. Його вибір був продиктований як особливостями темпераменту публіциста (пор.: «Загалом ми маємо достатньо підстав вважати, щ⿻о Донцьов за вдачею був досить важкою людиною. Про це, зокрема, не раз згадували С. Петлюра, В. Липинський, В. Винниченко, П. Скоропадський та інші» [Горєлов 1996:66]), так і політичною атмосферою навколо тодішньої України (пор.: «Ідё Донцуова ставляться під сумнів з огляду на їхню так звану атресивність, войовничість, нетерпимість, недемократичність... $A$ де ж засада адекватности часові? Европа за життя Дониуова - цее суцільний згусток антидемократичних, мілітарних та імперіалістичних режимів (Німеччина, Іспанія, Італія, СССР), які, мов хижі звірі, намагалися побороти один одного. Цікаво, як за таких умов, зберігаючи демократичність, виваженість, толерантність, пацฺифізм, можна було вижити Україні ц̆ украӥнцял?» 
[Червак 2005:78]).

Утім, вирішальне значення для напряму сугестії журналіста мала специфіка українського менталітету, у якому домінують надмірні м'якість, демократизм, толерантність. Саме ці риси, на думку вісниківського ідеолога націоналізму, спричинюють біди народу-носія. Д. Донцова обурює "ціла наша, вихована віками неволі, неагресивна, оборонна в своїй суті, психольогія... Се $є$ та психіка, яка сама не вірить в творчу силу свого обурення, яка розуміла українство не як спір за владу, лише - за “поліпшення долі”, не як боротьбу, лише як пристосовання, для якої українські постуляти були предметом дискусії - давніше 3 «Нов. Времям», нині - зі Сталіном, а не незбитими догмами” (Д. Д., Пр.:451). Р. Харчук так інтерпретує одне 3 аналогічних донцовських висловлювань: «Доктор Дониов вважав, що у нас люди і їх вигода ставляться вище ідей та характерів» [Харчук 1991:4]. Зрозуміло, що такі життєві настанови аж ніяк не сприяють утвердженню національної ідеї й усамостійненню України. Можна собі уявити, до якого відчаю доводило усвідомлення цього факту мислителя, який вітав усе, що працювало на користь нації, i засуджував деструктивні чинники. Переповнений розчаруванням, публіцист навіть висуває тезу про неповноцінність української нації, що не була позитивно сприйнята українською громадою. Д. Донцов постійно наполягає на ментальних трансформаціях. «... Він став, - пише Б. Пастух, - на певний час ідеологічним символом мілітарної доби, законодавием волюнтаризму. Не обставини над нами, а ми над ними", - там можна окреслити його життєве кредо» [Пастух 2008:85].

Чому саме волюнтаризм? Волюнтаризм, - читаємо у «Великому тлумачному словникові сучасної української мови», - «1. Ідеалістичний напрям у філософії, представники якого вважають людську волю першоосновою i творцем дійсності. 2. псих. Визнання волі, а не розуму основним у психічному житті людини. 3. Довільні рішення, що ігнорують закони історичного розвитку, реальні умови та обставини» [ВТС СУМ 2009:202]. Я. Радевич-Винницький зазначає, що, за переконанням вісниківського журналіста, в українській 
ментальності повинен бути «суттєво посилений вольовий чинник, котрий узяв би під свій контроль нашу злощасну емоційність з ії вибуховістю, хвилевістю (короткотривалістю), нецілеспрямованістю, замкненістю на собі чи на малій групі, відсутністю вірності, інтенцією до “волі”, котра часто провадить до “анархізму”» [Радевич-Винницький 1997:202-203]. Віддавши належне матеріалізму, Д. Донцов став прихильником ірраціоналізму-волюнтаризму, через посередництво якого сприймав навколишнє середовище 31913 р. Чимало прислужилися до світоглядної еволюції майбутнього вісниківця волюнтаристичні ідеї Шопенгауера та Ніцше. Услід за ними він доводив, що найголовнішу роль у суспільних процесах відіграє воля, “сліпа воля, воля без раціональної мети, як імпульс до самооб'єктивізації, до існування...” [Сайко 2004:490]. Пріоритетна роль у житті особи й суспільства відводиться ірраціональній “волі до життя”. На сторінках “Літературно-Наукового Вістника” (“Вістника”) журналіст позиціонує іï як «внутрішній стимул до боротьби» [Дорожинський 1993:207].

Ідея волюнтаризації української мовної ментальності іррадіює крізь вісниківський дискурс Д. Донцова, спричинюючи його імперативність. Ми схиляємось до думки тих дослідників, які неоднозначно сприйману у донцовознавстві стильову імперативність уважають вмотивованою i виправданою логічними висновками публіциста [див., напр., Різниченко ЕР]. Для нерішучого й невпевненого в собі читача «Літературно-Наукового Вістника» (“Вістника”) донцовські директиви ставали безпосереднім керівництвом до дії, гартували його волю, вчили діяти стрімко і з гідністю.

Найуживанішими засобами вираження вісниківських імперативів стали дієслівні форми 1-ої та 2-ої особи множини, рідше 2-ої особи однини наказового способу.

Особливі надії покладаючи на виховання душі нового покоління українців, головний редактор ЛНВ закликає читачів часопису до наслідування кращих світових зразків, як-от: Ми, щзо все оглядаємося на задні колеса, щзо боїмося вилізти з своєї клуні (де сіно таке мягке!), і ми, яких лякають “проміні 
міських вогнів”, - вчімось від Америки ї̈ божевільного темпу життя, ї̈ галасливого гону наперед! Ми, щзо так вирозумілі для власного галапасництва $i$ неробства, вчімось американської суворости до себе, вимагаючої для добрих $i$ немилосерної для лихих? Ми, щзо попадаємо в паніку по кожнім ударі, вчімось від Американців мужности в нещзастью $i$ завзятости в біді! Ми, з намою нудною иеремоніяльністю і дрибязковою образливістю - вчімось американськоӥ щзирости $i$ безпосередности! Ми, щзо так легко (для святого спокою) потураємо громадським икідникам, - зрозуміймо, щзо то є терор американської громадської думки! (Д. Д., Д.ам., 371).

Зі смисловою тональністю перетворення невільників у борців кореспондують у вісниківському дискурсі й такі імперативи: $A$ nidнесіmb nротест проти Гетта, проти замкнутости (Д. Д., Н.літ.г.:81); “..ㅁикуйте собі мужню дуиу $i$ відважне серизе!” (Мерсє) (Д. Д., П. чи Екл.:180); “...루imься духом... He губіть надіï” (Петлюра) (Д. Д., Зг. в сім.:606); Не бійтеся, (націоналізм - Л.С.) знайде його (ідеал - Л.С.).. (Д. Д., Патр. і нац.:80); ...Патер Годой, перед масакрою, заохочував їх (місіонерів - Л.С.) словами: “Не зраджуйте прапору!” (Д. Д., Єд., що є:79-80); Чому проти большевізму не уживалося у нас мови нпр. сього культурного француза: ...бивайте, як вас вбивають... Витереблюйте нікчемну наволоч, щзо трактує вас як псів. Покажіть, що нікчемну пиху насильства теж може досягнути наша помста... (Д. Д., Нер.мог.:298); “Вірте мені, щзо Божа рада... є ліпша від вашої й від усіх инших людей” (Жанна д’Арк) (Д. Д., Ж.д.:552); Не робім собі

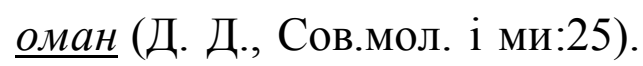

Опоненти Д. Донцова роблять йому закид про надмірне захоплення ідеєю нового типу українця, який нібито межує 3 радянською надлюдиною. Висловлюються також думки про намагання Дмитра Донцова прищепити українцям невластиві їм риси й ознаки, тобто здійснити насилля над їхньою ментальністю. Василь Іванишин спростовує ці твердження. Він наголошує, що «Донцов жодної з якостей, які він хотів бачити у своєму народі, не видумував i не привносив ззовні» [Іванишин 2008:47]. Він намагався відродити втрачені за 
віки неволі іманентні риси українського етносу. Тому постійно апелював до історичної пам'яті сучасників, що засвідчує й дискурс “Літературно-Наукового Вістника", напр.: Перегорність старі книги старих традииій, а віднайдете в них тверду душу забутих предків, щзо в воді не тонули $i$ в вогні сміялися... (Д. Д., Н. і В.:255); Пригадайте собі... що відповіли козаки смутної памяти воєводі Кисілеві... (Д. Д., Ав.нас.:739); I знову, даремно тисячю глосів $i$ відгомонів гукала до них історія: протріть очі! (Д. Д., Мог.дем.:747); Але вглибіться в ту фільософію і порівнайте іï з сучасною (Д. Д., Н. і В.:253); Пригадайте Шевченкову оиінку сього народу, пригадайте народні прислівя... (Д. Д., Нер.мог.:288).

Віддаючи належне українським традиціям, вісниківський редактор уважає за необхідне орнаментувати виклад елементами окциденталізму. Загалом Д. Донцова вважають людиною “західньої орієнтації. Туди, - пише М. Прокоп, - він також спрямував українську політичну думку, українську духовість” [Прокоп 1993:521]. У статтях публіциста це спрямування здобуло форму активних настанов: ... Читайте історію Клємансо... (Д. Д., М. і пр.:341);

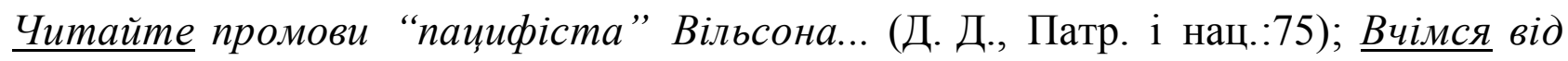
чужсиниів! (Д. Д., Пр.пок.:326); Що значить диктатура? Сmудіюйте події у Вiдні, у Франиії (Д. Д., До конс.:305); Погляньте на Італію перед 1922 роком... (Д. Д., За з.д.:83).

Основне спрямування донцовських директив - це зміни у сфері духа, у ментальності українців. Вітчизняні “скарікатуризовані, в призмі їх ідеалу, постаті” пропонується зіставити “з постатями Кромвеля, Данте, Колінса, - 3 тими, мов з бронзи вилятими постатями непохитної ідеї, суворого серця” (Д. Д., Зг. в сім.:588). “Сатанські постати Б а р б е йд ' О р е в і л ь ї”, звіробоїв М онте рляна", “Вотрена Бальзака або бандитів М ерім е” публіцист закликає згадати, щоб переконатися, що “навіть у своїм гріху сі особистости - непокірні до останку” (Д. Д., Р. чи Евр.:66). Реставрувати втрачені ментальні особливості, маючи за зразок європейську ідею національної та особистої свободи - таке завдання ставить Д. Донцов, політик і 
журналіст, перед українським етносом. Його розв'язання він вважає необхідною передумовою державотворчого поступу українців.

Функцію імперативів у вісниківських статтях Д. Донцова виконують дієслова борись, вернім, вертаймо, визнайте, відійдіть, відіймай, візьмім (візьміть), встань, гляди (глядіть), годи, голосім, грабь, гуртуймося, загляньмо (загляньте), задаймо, зазначуймо, залимім, замінім, запитаймося (запитайтеся), зачинай, зверніться, згадаймо (згадайте), здаймося, зіставте, змийте, знищзіть, зрозумійте, їдте, йди (йдітьже), киньте, латаймо, лишім, лишімся, молись, назвім, не вдавайтеся, не говорім, не гріши, не женіться, не журіться, не забуваймо, не кинь, не клади, не оцінюйте, не піддавайтеся, не роби, не товчіть, памятаймо (памятайте), перекиньмо, перенесімся, перечитайте, підім (підіть), піднесім, повалім, погляньмо (погляньте), подивіться, подумайте, познайомтеся, покажіть, покиньте, поладнаймо, порівнайте (порівніть), поставмо (поставте), постараймося, потішмо, працүюйте, приборкайте, пригадаймо (пригадайте), пригляньмося, приймаймо, приймім, припустім, приходьте, проаналізуйте, продовжуймо, прокинься, простіть, протріть, прочитайте, ратуйся, робіть, розгорніть, розгляньмося, розиирюйте, сідайте, скажім, скиньмо, слухайте, спитайте, спіть, спробуймо (спробуйте), стережися (стережіться), стривайжеж, трезвись, удавайтеся, ужиймо-ж, учись, уявіть, хапайте, ходи, чекайте, читай (читайте), иукаймо. Окремі 3 них декількаразово повторюються. На наш погляд, така кількість дієслів наказового способу покликана здійснити вплив не тільки на свідомість, а й на підсвідомість читачів, динамізувати дещо повільного, а інколи й інертного та пасивного українця.

До речі, імперативи Д. Донцова не тільки закликають, інколи за їхньою допомогою висловлюється застереження. У “старого Плятона” публіцист рекомендує зазирнути, щоб пересвідчитися, що “звістуном кінця демократичної еліти був факт, що “керманичі зачинали мати вигляд кермованих" (Д. Д., Принаг.:1020). Однак, Донцову-журналістові більше імпонує категоричний імператив. Так, ідеальним громадянином він уважає того, хто 
“ х о ч е (активна прикмета!) здійснити категорічний імператив країни, що прагне жити сама для себе” (Д. Д., Патр. і нац.:79).

Створенню категоричної директивної тональності значною мірою сприяє широке вживання конструкцій “треба + інфінітив”. Читач “ЛітературноНаукового Вістника” (“Вістника”) постійно отримує інструкції, які здійснюють корекцію його діяльності: треба запитати (Д. Д., Ц. і нац.:75); треба вдихнути (Д. Д., Укр.-сов.пс.:335); треба глядіти (Д. Д., Ж.д.:556); треба вибирати (Д. Д., Д.ам.:371); не треба думати (Д. Д., П. чи Екл.:180); треба дивуватися (Д. Д., Що т.нац.:357); треба вірити (Д. Д., Персп.:467); треба памятати (Д. Д., Від К.М. до А.С.:921); треба пригадати (Д. Д., Жовт. і м.:328); треба не забувати (Д. Д., Шат.мал.:273); треба шукати (Д. Д., Укр.-сов.пс.:334); треба дивитися (Д. Д., Ав.нас.:827); треба боротися (Д. Д., Ав.нас.:830); треба не допустити (Д. Д., До конс.:306); треба вимітати (Д. Д., До конс.:307); треба завважити (Д. Д., 1709:564); не треба забувати (Д. Д., М.Хв.:609); треба звернути увагу (Д. Д., Ст. як д.Укр.:890); треба звернутися (Д. Д., Заг. III імп.:V); треба розріжняти (Д. Д., Нер.мог.:285); треба поставити (Д. Д., Бур.над Зах.:225); треба скінчити (Д. Д., Два ант.:666); треба демаскувати (Д. Д., До конс.:306) та інші. Семантика цих висловів здебільшого позначена донцовським максималізмом: публіцист наполягає на якнайшвидшому подоланні старого й одночасному продукуванні нового в навколишньому світі й особливо - у душах людей (пор.: ...Cтаре mpeба перемогти в своїм сериі. Треба перестати розуміти світ як терпіння, лише відчути його як волю $і$ чин (Д. Д., Спр.Пр.:85)). Фактично це заклик до зміни провідних ментальних особливостей етносу.

Інколи Донцов-журналіст одним реченням накреслює реципієнтам часопису розширену програму їхньої діяльності (див.: $\underline{\text { Tреба }}$ лище $\underline{\text { не }}$ піддаватися гістерії, панікерству, не брати початок кіния большевизму за початок його стабілізації, не понижувати клича, під яким іде боротьба в СССР, $i$ вичеркнути раз на все з свого лєксикону слово - федерація (Д. Д., Поч.к.:850). Індексуючи “жорсткість, імперативність, динамізм думки” 
[Різниченко EP] автора, такі пасажі стали можливими завдяки його таланту помічати й чітко формулювати головне.

Iз розряду обов’язкових до виконання також настанови, що містяться в конструкціях типу “мусимо + інфінітив”, напр.: мусимо знищчити (Д. Д., Персп.:467); мусимо змагати (Д. Д., До конс.:307); мусимо викинути (Д. Д., 1937:61); мусимо боротися (Д. Д., 1937:68); мусимо упритомнити (Д. Д., Сов.мол. і ми:24); мусимо викохати (Д. Д., Від К.М. до А.С.:922) тощо. Трапляються також конструкції “повинні + інфінітив”: повинні придивлятися (Д. Д., Д.ам.:371); повинні вчитися (Д. Д., Д.ам.:371); повинні придбати (Д. Д., Кр.вп.:183); повинні стати сучасниками (Д. Д., Кр.вп.:183). Ми далекі від думки, що такі вислови являють собою готові політичні рецепти, однак не можемо заперечувати їхню координаційну роль щодо розвитку мовної ментальності реципієнтів у напрямку волюнтаризації.

Ясність і логічність тез Д. Донцова забезпечувалась, окрім іншого, своєрідним “барабанним” (Р. Рахманний) викладом, в арсеналі якого комунікативні одиниці 3 предикативною основою, вираженою одиничним інфінітивом. Такі конструкції мають значення категоричних наказів i передбачають беззастережне виконання. В умовах політичної безвиході журналіст пише: “Стрясти 3 себе дурман завойовницької комуністичної ідеольогіiі, $\underline{\text { не }}$ вирекатися себе й своєї крови, піднестися 3 морального упадку, проголосити смерть комунізмові і своє право - як кляси i нації - на істновання" (Д. Д., Про с.-ід.:466). Є у вісниківського редактора й спеціальні рецепти для “нашої скаліченої душі”: Відкинути наші усвячені віками хитання з права на ліво, щуоби засвоїти собі американський догматизм. Засвоїти, замість намої зневіри $i$ панікерства - їх віру в себе $і$ любов до життя. Замінити наму плєбейську заздрість до всього, щуо над нами - на їх демократію - щзоб усе низьке стало високим. Навчитися, щуо вище від нашого запобігання ласки всіх $i$ вся - $\epsilon$ нацуінальна гордість янкі, щуо не зносить труйливого повітря інтернаціоналізму, а над собою - жодних вищих рас... (Д. Д., Д.ам.:371). Одним словом, “змінити серця” (Д. Д., Бол.дем.:935). I рефреном звучить думка про те, що на краю могили, 
де опинилась українська нація, “зробити це можна не демократичними методами” (Д. Д., Бол.дем.:935).

Таким чином, волюнтаризація української ментальності, за Д. Донцовим, - обов’язкова умова державності України. Вісниківські імперативи Донцова становлять собою одну з форм волюнтаристичного впливу на мовну ментальність читачів “Літературно-Наукового Вістника" (“Вістника").

\section{БІБЛІОГРАФІЯ}

ВТС СУМ 2009 - Великий тлумачний словник сучасної української мови (з дод., допов. та CD) / уклад. і голов. ред. В.Т. Бусел. - К.; Ірпінь: ВТФ “Перун”, 2009. - 1736 с.: іл.

Горєлов 1996 - Горєлов М.Є. Дмитро Донцов. Штрихи до політичного портрету / Микола Горєлов // Горєлов М.Є. Передвісники незалежної України. Історичні розвідки / Микола Горєлов. - К.: Вид-во “РАДА”, 1996. - С. 59-86.

Дорожинський 1993 - Дорожинський П. Дмитро Донцов - критика деяких його поглядів на націоналізм (Дмитро Донцов i організований український націоналізм) / Павло Дорожинський // ОУН: минуле і майбуття: збірник / відп. редактор С. Таран, відп. за випуск Н. Караванська. - К. : Фундація ім. О. Ольжича, 1993. - С.203-212.

Іванишин 2008 - Іванишин П. “Естетика Шевченка" як сутність герменевтики Дмитра Донцова / Петро Іванишин // Дивослово. - 2008. - №10. C. 52-56.

Пастух 2008 - Пастух Б. Володимир Винниченко і Дмитро Донцов: онтологічний конфлікт / Богдан Пастух // Слово і час. - 2008. - №10. - С.84-89.

Прокоп 1993 - Прокоп М. Дмитро Донцов (1883-1973) / Мирослав Прокоп // Прокоп М. Напередодні незалежної України. Спостереження i висновки. - Нью-Йорк - Париж - Сидней - Торонто - Львів: Наукове товариство ім. Шевченка, 1993. - Бібліотека Українознавства. - Т. 62. C. 511-523. 
Радевич-Винницький 1997 - Радевич-Винницький Я. Україна: від мови до нації / Я. Радевич-Винницький. - Дрогобич : Видавнича фірма “Відродження”, 1997. $-360 \mathrm{c}$.

Різниченко ЕР - Різниченко О. Деякі світоглядові, естетичні і стильові параметри публіцистики Дмитра Донцова (на прикладі аналізу роботи “Підстави нашої політики”) / Ольга Різниченко [Електронний ресурс]. - Режим доступу: http://oun-upa.info/bachup/ukrnationalism/24.doc.

Сайко 2004 - Сайко О. Мова і нація: філософський та психологічний аспекти / О. Сайко // Вісник Львів. ун-ту. - Серія журналістики. - 2004. Вип.25. - С. 488-491.

Супрун 2012 - Супрун Л.В. Мовноментальні особливості комунікаційної системи «Літературно-Наукового Вістника»: монографія / Л. В. Супрун. Вінниця : Вінницька обласна друкарня, 2012. - 507 с.

Харчук 1991 - Харчук Р. Повернення Дмитра Донцова / Роксана Харчук // Донцов Д. Історія розвитку української державної ідеї. - К. : Товариство “Знання” України, 1991. - С. 3-5.

Червак 2005 - Червак Б. Дмитро Донцов і український націоналізм / Богдан Червак // Розбудова держави. - 2005. - №1-4. - С. 77-81.

\section{СПИСОК УМОВНИХ СКОРОЧЕНЬ}

Д.Д., Ав.нас. - Донцов Д. Авіронове насіння / Дм. Донцов // Вістник. 1937. - Річник V. - Том IV. - Книжка 10. - С.731-755; Книжка 11. - С. 803-830.

Д.Д., Бол.дем. - Донцов Д. Болячка демократизму / Д. Д. // Вістник. 1933. - Річник I. - Том IV. - Книжка 12. - С. 929-936.

Д.Д., Бур.над Зах. - Донцов Д. Буря над Заходом / Дм. Донцов// Вістник. - 1934. - Річник II. - Том I. - Книжка 3. - С. 223-227.

Д.Д., Від К.М. до А.С. - Донцов Д. Від Карла Маркса до Адама Сміта (Вигляди совітського самодержавя) / Д. Донцов // Літературно-Науковий Вістник. - 1931. - Річник XXX. - Том CVII. - Книжка X. - С. 909-922.

Д.Д., Д.ам. - Донцов Д. Дух американізму / Д. Донцов // ЛітературноНауковий Вістник. - 1929. - Річник XXVIII. - Том XCLIII. - Книжка IV. Літератури світу: поетика, ментальність і духовність. - 2015. - Вип.6. 
C. $357-371$.

Д.Д., Два ант. - Донцов Д. Два антиподи (Шевченко і Драгоманов) / О. В. // Вістник. - 1938. - Річник VI. - Том III. - Книжка 9. - С. 653-666.

Д.Д., До конс. - Донцов Д. До консолідації / Дм. Донцов // Вістник. 1934. - Річник II. - Том II. - Книжка 4. - С. 301-307.

Д.Д., Єд., що $є-$ Донцов Д. Єдине, що $є$ на потребу (Новорічні рефлєксії) / Дм. Донцов // Літературно-Науковий Вістник. - 1930. - Річник XXIX. - Том CI. - Книжка I. - С. 74-85.

Д.Д., Ж.д. - Донцов Д. Жанна д’Арк (Історія і лєгенда) / Дм. Донцов // Літературно-Науковий Вістник. - 1929. - Річник XXVIII. - Том XCIX. - Книжка VI. - C.545-556.

Д.Д., Жовт. і м. - Донцов Д. Жовтень і май / Д. Д. // ЛітературноНауковий Вістник. - 1927. - Річник XXVI. - Том XCIII. - Книжка VI. С.171-186; Книжка VIII. - С. 323-336.

Д.Д., Заг. III імп. - Донцов Д. Загадка III-ої імперії / Д. Д. // Вістник. 1939. - Річник VII. - Том II. - Книжка 5. - С. 326-342.

Д.Д., За з.Д. - Донцов Д. За завтрішній день / Дм. Донцов // ЛітературноНауковий Вістник. - 1928. - Річник XXVII. - Том XCV. - Книжка I. - C.83-87.

Д.Д., Зг. в сім. - Донцов Д. “Згода в сімействі” / Дм. Донцов // Вістник. 1936. - Річник IV. - Том III. - Книжка 7-8. - С. 587-606.

Д.Д., Кр.вп. - Донцов Д. Крок вперед (До “літературного” спору)/ Д. Донцов // Літературно-Науковий Вістник. - 1926. - Річник XXV.Том XCI. - Книжка X. - C. 167-183.

Д.Д., М. і пр. - Донцов Д. Маса і провід / Дм. Донцов // ЛітературноНауковий Вістник. - 1930. - Річник XXIX. - Том СI. - Книжка III. - С. 263-279; Книжка IV. - С. 331-351.

Д.Д., Мог.дем. - Донцов Д. Могікани демократії / Дм. Донцов // Вістник. - 1935. - Річник III. - Том IV. - Книжка 10. - С. 746-753.

Д.Д., М.Хв. - Донцов Д. Микола Хвильовий / Дм. Донцов // Вістник. 1933. - Річник I. - Том III. - Книжка 7-8. - С. 591-609. 
Д.Д., Нер.мог. - Донцов Д. Нерозрита могила / Дм. Донцов // Вістник. 1937. - Річник V. - Том II. - Книжка 4. - С. 283-302.

Д.Д., Н. і В. - Донцов Д. Нині і Вчора / Д. Д. // Літературно-Науковий Вістник. - 1931. - Річник XXX. - Том CV. - Книжка III. - С. 239-255.

Д.Д., Н.літ.г. - Донцов Д. Наше літературне гетто / Дм. Донцов // Літературно-Науковий Вістник. - 1932. - Річник XXXI. - Том CVIII. Книжка I. - С. 68-84.

Д.Д., Патр. і нац. - Донцов Д. “Патріотизм” і націоналізм / Д. Д. // Літературно-Науковий Вістник. - 1927. - Річник XXVI. - Том XCIV.Книжка IX. - С. 62-82.

Д.Д., Персп. - Донцов Д. Перспективи (по 25 травня 1926) / Д. Д.// Вістник. - 1936. - Річник IV. - Том II. - Книжка 6. - С. 452-469.

Д.Д., Поч.к. - Донцов Д. Початок кінця / О. В. // Вістник. - 1933. Річник I. - Tом IV. - Книжка 11. - C.847-850.

Д.Д., Пр. - Донцов Д. Процес / Д. Д. // Літературно-Науковий Вістник. 1930. - Річник XXIX. - T.CII. - Книжка V. - С. 447-453.

Д.Д., Принаг. - Донцов Д. Принагідно / Д. Д. // Літературно-Науковий Вістник. - 1931. - Річник XXX. - Том CVII. - Книжка XI. - C. 1015-1020.

Д.Д., Про с.-ід. - Донцов Д. Про соціял-ідіотів / Д. Донцов // ЛітературноНауковий Вістник. - 1932. - Річник XXXI. - Том CVIX. - Книжка V.C. $452-466$.

Д.Д., Пр.пок. - Донцов Д. Проблєма поколінь / Д. Донцов // ЛітературноНауковий Вістник. - 1928. - Річник XXVII. - Том XCVI. - Книжка VII-VIII. C. $318-328$.

Д.Д., П. чи Екл. - Донцов Д. Патріа чи Еклєзіа? / Д. Д. // ЛітературноНауковий Вістник. - 1928. - Річник XXVII. - Том XCVII. - Книжка X. C. $170-182$.

Д.Д., Р. чи Евр. - Донцов Д. Росія чи Европа? (До літературної суперечки) / Дм. Донцов // Літературно-Науковий Вістник. - 1929. - Річник XXVIII. - Том XCLIII. - Книжка I. - C. 62-79. 
Д.Д., Сов.мол. і ми - Донцов Д. Совітська молодь і ми / Дм. Донцов // Вістник. - 1933. - Річник I. - Том I. - Книжка 1. - С. 17-32.

Д.Д., Спр.Пр. - Донцов Д. Спростачений Прометей (“Тарас Шевченко” ВУФКУ) / Д. Д. // Літературно-Науковий Вістник. - 1929. - Річник XXVIII. T. XCLIII. - Книжка I. - C. 80-85.

Д.Д., Ст. як д.Укр. - Донцов Д. Сталін як “добродій” України / О. В. // Вістник. - 1936. - Річник IV. - Том IV. - Книжка 12. - С. 890-896.

Д.Д., 1937 - Донцов Д. 1927 / Д. Донцов // Літературно-Науковий Вістник. - 1937. - Річник V. - Том I. - Книжка I. - С. 54-66.

Д.Д., 1709 - Донцов Д. 1709-1739 (памяти мазепинців) / Д. Д. // Вістник. 1939. - Річник VII. - Том III. - Книжка 7-8. - С. 559-565.

Д.Д., Укр.-сов.пс. - Донцов Д. Українсько-совітські псевдоморфози / Д. Донцов // Літературно-Науковий Вістник. - 1925. - Річник XXIV. Том LXXXVIII. - Книжка XII. - C. 321-336.

Д.Д., Ц. і нац. - Донцов Д. Церква і націоналізм / Д. Д. // ЛітературноНауковий Вістник. - 1924. - Річник XXIII. - Том LXXXIII. - Книжка V-IX. C. $75-82$.

Д.Д., Шат.мал. - Донцов Д. “Шатость малоросійская” / Д. Д. // Літературно-Науковий Вістник. - 1927. - Річник XXVI. - Том XCII. Книжка III. - С. 265-275.

Д.Д., Що т.нац. - Донцов Д. Що таке нація? / О. В. // Вістник. - 1937.Річник V. - Том II. - Книжка 5. - С. 354-360. 